\title{
Towards a framework for critical citizenship education
}

\begin{abstract}
Increasingly countries around the world are promoting forms of "critical" citizenship in the planned curricula of schools. However, the intended meaning behind this term varies markedly and can range from a set of creative and technical skills under the label "critical thinking" to a desire to encourage engagement, action and political emancipation, often labelled "critical pedagogy". This paper distinguishes these manifestations of the "critical" and, based on an analysis of the prevailing models of critical pedagogy and citizenship education, develops a conceptual framework for analysing and comparing the nature of critical citizenship.
\end{abstract}

Keywords: citizenship education, critical thinking, critical pedagogy, citizen participation

\section{Introduction}

In the last twenty years or so school systems around the world have undergone a plethora of reform measures designed to reorient and/or strengthen the role of citizenship education. This has ranged from the introduction in many nations of new school subjects and crosscurricular themes (under a range of curriculum labels including citizenship, civics, democratic education, national education, and political education) to major reforms of existing curricula. Whilst historically the primary role of citizenship and civics education in nation states was linked with the process of state formation and designed to build a common identity, inculcate patriotism and loyalty to the nation (Green 1990), it is now often expected to achieve a far more complex set of purposes which broadly reflect changing conceptions of what it means to be a good citizen. Major shifts which have contributed to this change and the consequent reform of citizenship curricula, beyond a concern for membership of a nation state, include: the emergence of global and crossnational bodies such as the UN and EU, creating pressures for schools to promote forms of supranational citizenship; multiculturalism, limiting the validity of ethno-nationalistic forms of identity; and associated attempts to promote forms of citizenship based on the promotion of a common set of shared values (e.g. tolerance, human rights and democracy) which prepare young people to live together in diverse societies and which reject the 
divisive nature of national identities. In some contexts citizenship education is also expected to contribute to the promotion of social justice, social reconstruction and democracy.

Further demands have been placed on citizenship curricula around the world by the expectation that they encourage citizens to be "critical". The promotion of forms of critical citizenship reflects the longstanding attempts by societies to address what Tyack and Cuban (1995) describe as one of the perennial dilemmas of schooling, namely the desire on the one hand to ensure an obedient populace and on the other hand to ensure that citizens are creative and critical. The importance of achieving the latter dimension has been reinforced greatly by the instrumental desire of states to strengthen their competitiveness in the global economy, which is seen to require a more innovative, independent, creative and reflective workforce.

Documents defining the nature of citizenship curricula use the word "critical" within a variety of forms including for example 'critical thinking' and 'critical skills' in England (Qualifications and Curriculum Authority 2007); and, in France, 'critical spirit' (Ministère de l'Education Nationale 2004). Despite the similarity in terminology, these descriptors mask very diverse expectations about what and how pupils will/should learn and reflect Edelsky and Cherland's (2006, p. 18) observation that the term 'critical' is in very common use and has essentially 'become a buzzword', a 'currently popular term or slogan that lacks precise meaning'.

From the citizenship educator's perspective, this ambiguity opens up the space for the term "critical" to be interpreted from the standpoint of critical pedagogy, which stresses the need for political engagement. Whilst citizenship education in England is often linked to the work of Paulo Freire by scholars who promote more active forms of citizenship (for example, Arthur and Davies 2008; Lawson 2005), such connections are rarely made 
explicit in curricular and associated documents. In contrast, the term "critical thinking" is promoted wholeheartedly in English curricular mandates, often accompanied by clarifications such as 'exploring, developing, evaluating and making choices' (Qualifications and Curriculum Authority 2007). Two questions thus arise which are addressed in this article: firstly, how are "critical thinking" and "critical pedagogy" distinct? And secondly, to what extent might spaces exist for citizenship educators to promote the latter within the bounds of the formal curricula for citizenship education?

In its investigation of the first question, this paper explores the nature of, and distinctions between, the two conceptions of critical citizenship described above, namely critical pedagogy and critical thinking. Having distinguished those elements which are particular to critical thinking and critical pedagogy, through an analysis of the burgeoning literature from both fields, the paper focuses on the literature which has promoted specific elements of critical pedagogy and develops a conceptual framework which relates these to characteristic curricular language regarding the desired knowledge, skills, values and dispositions of students. The application of this framework allows forms of critical citizenship to be distinguished and may reveal 'spaces' for critical pedagogy within the various levels and manifestations of school curricula, including policy documents, programmes of study and the practical experiences of pupils. The body of the paper divides into three sections: a review of the literature contributing to the conceptualisation of critical citizenship; development of the framework itself; and a brief investigation of the framework's practical implications and potential limitations.

\section{Critical Pedagogy, Critical Thinking and Critical Citizenship}

The word "critical" in its educational context can be found in a diverse range of literature where it is given a range of meanings. This section briefly compares and contrasts the 
fields of "critical thinking" and "critical pedagogy" and identifies elements that go beyond the former in order to contribute towards an analytical framework for critical pedagogy in citizenship education.

\section{Critical Thinking}

While conceptions of critical thinking in the literature tend to be based around the application of logic and being able to reach 'sound' conclusions (Doddington 2008, p. 109), there is disagreement within the field as to the extent to which critical thinking can go deeper, potentially developing a moralistic (focusing on values) or ideological (focusing on power) concern in students. Giroux (1994) argues that a moral orientation is entirely missing from most conceptions of critical thinking, and this is echoed by Lipman (2003) who suggests that with regard to his three 'categories of thinking' (critical, creative and caring), critical thinking is a 'theoretic science', entirely separate from the emotional, 'moral' category of 'caring thinking'. Moon (2008, p. 56), however, holds that critical thinking that involves metacognitive activity (thinking about one's thinking) or that concerns critical thinking 'as a way of being' is 'deeper' than thinking that concerns skills and processes only. Martin (1992) goes further in arguing that critical thinking is founded in moral perspectives and should be motivated by concerns for a more just and humane world but is clearly in the minority within the field of critical thinking (Burbules and Berk 1999).

The scope of critical thinking for becoming more than just "thinking" is also disputed. Barnett (1997) argues that it must include 'disciplinary competence' (knowledge); 'critical self-reflection' (metacognition) and 'critical action', but the call for critical action does not reflect the position of most critical thinkers, as it transgresses into the domain of critical pedagogy rather than the typically more apolitical critical thinking. 


\section{Critical Pedagogy}

The term 'critical pedagogy' describes that body of literature that aims to provide a means by which the oppressed (or 'subaltern') may begin to reflect more deeply upon their socio-economic circumstances and take action to improve the status quo. Recent manifestations have been variously termed 'radical pedagogy', 'liberatory pedagogy', ‘revolutionary pedagogy', 'oppositional pedagogy’ and ‘border pedagogy’ (Au 2007; De Lissovoy and McLaren 2006; Giroux 2003; Green 1997; Hill 2003).

The roots of critical pedagogy lie in the critical theories of the Frankfurt School (most notably Adorno, Habermas, Horkheimer and Marcuse) and are most directly associated with the teachings of Paulo Freire, a Brazilian educator whose seminal work Pedagogy of the Oppressed captured the imaginations of many educators and academics across the world. Freire (1972) brought a fiercely Marxist approach to his work with illiterate adult workers in Brazil. He developed pedagogical methods and a philosophy of education in which he argued that the 'banking' approach to education constituted a great hegemonic oppression and that, in order to free the people, educators needed to develop context-specific pedagogical methods through which teachers and pupils used dialogue to open up the critical consciousness of the people ('conscientização', or conscientization). The notion of praxis was central to these methods, by which Freire meant a synergistic process of reflection and action through which the people would become 'involved in the organized struggle for their liberation' (Freire 1972, p. 40).

Following the publication of Pedagogy of the Oppressed, many educationalists took up the banner of critical pedagogy and its close associate, 'critical literacy' and, at the beginning of the $21^{\text {st }}$ century, as McLaren (2003, p. 69) states, 'critical pedagogy is as diverse as its many adherents'. However, DeLeon brings out common themes from the 
diverse literature and identifies their common goals as: "viewing education as a political act... transforming schools towards pursuing social justice... [and] using education to engender social change and empower educational actors" (DeLeon 2006, p. 2). These goals indicate a strong political element which echo Burbules and Berk’s (1999, p. 55) attempt to pin down the distinction between critical thinking and critical pedagogy: 'Critical thinking's claim is, at heart, to teach how to think critically, not how to think politically; for critical pedagogy, this is a false distinction'.

\section{Critical Thinking and Critical Pedagogy}

The boundaries between critical thinking and critical pedagogy have thus become blurred, but we can identify from the literature ten elements associated with critical thinking and critical pedagogy which are shown in Figure 1. Of the ten elements, some, such as 'praxis', are primarily or specifically associated with critical pedagogy and others, such as an 'abstract focus', are specific to critical thinking. Others, such as dialogue, or argument, would seem to be common to both.

\section{Insert Figure 1 about here}

Four elements in Figure 1 are therefore identified as distinguishing critical pedagogy from the more neutral notion of critical thinking: the ideological/moral; the collective/social; the subjective/context-driven; and praxis (reflective action). The relationship between these elements and citizenship education is explored below, firstly in order to clarify the varied terminology used by many critical pedagogues; secondly to 
consider the ideas of some of their critics; and finally to begin to outline a potential structure for the framework for critical citizenship education.

\section{Distinctive Features of Critical Pedagogy}

\section{Ideology and Politics}

This element associates the terms "politics" and "ideology": although citizenship educators are more accustomed to the former term. The current literature in this area of critical pedagogy frequently refers to theories of "ideology and power" and "oppression and injustice".

Darder, Baltodano and Torres (2003, p. 13) define ideology as 'the framework of thought that is used in society to give order and meaning to the social and political world in which we live'; this framework for many critical pedagogues is associated with Marxist philosophy or one of its successors (neo-Marxism; post-Marxism; Marxist feminism and so on). However, there is a long-standing debate as to whether Marxism is an essential tenet of the ideology of critical pedagogy. Certainly the language of critical pedagogy centres around the language of power used by Marx (1867/1999), Gramsci (1971) and other prominent Marxist thinkers, and the anti-capitalist ideology of a number of critical pedagogical writers is expressed in no uncertain terms:

Humanity may let itself be led by capitalism's logic to a fate of collective suicide or it may pave the way for an alternative humanist project of global socialism. (Scatamburlo-D'Annibale and McLaren 2004, p. 194)

While Gibson (1986) argues that within any deep critique of society it is likely that critical theorists will 'find enormous difficulty in not locating the root of all social ills in economic relationships' (Gibson 1986, p. 6, original emphasis), it is difficult, as Green (1997) suggests, to align the macro-social explanations of Marxism with relativist postmodern interpretations such as Giroux’s $(1992 ; 2005)$ 'border pedagogy’, which aims 
to 'traverse' disciplines such as feminism, race and identity politics, postmodernism, postcolonialism and cultural studies. Current criticisms of critical pedagogues often centre on their use of postmodern approaches: there is particular disapproval of their over-use of 'their own neologisms (newly-coined words)' (Gibson 1986, p. 16). It is also acknowledged, even by those "inside" the field, that the association of critical pedagogy with the more individualistic postmodernist perspectives has "opened up" critical pedagogy to the range of criticisms of that perspective and specifically that it is 'too theoretical, abstract, esoteric, and out of touch' (Apple 2000, p. 253); 'proudly unpragmatic'; and connected 'poorly with life in the classroom' (Wrigley 2006, p. 179).

It is important to emphasise that critical pedagogy does not necessarily subscribe to a Marxist or equivalent viewpoint ${ }^{1}$, although there have been recent calls to distance it from postmodernism and move 'back' towards an ideological focal point (McLaren 2001). While the moralistic goals of critical pedagogues may align with those of liberal and "social democratic" educationalists wishing to promote 'equality, dignity, security, and participation' (Osler 1998, p. 125), their visions of the root causes of injustice, as well as the methods they advocate to combat injustice, are somewhat different. The critical pedagogues' view that the struggle against injustice is a fight for 'emancipation' (Giroux 2003) rather than 'freedom' (Sen 1999) is a subtle but important distinction resting on the powerful concept of oppression.

De Lissovoy (2008, p. 84) laments the 'variety of directions' from which critical pedagogy approaches the 'problem of oppression and education' and suggests that they should be 'connected to standpoints' (common epistemological worldviews arising from a particular social, cultural or economic position), based on the theories of Lukács (1971). The 'standpoints' from which oppression theories could arise are wide-ranging and might 
include the following: feminist / gender-based; class-based; race-based; Queer Theories; and Post-colonial theories.

Whilst education is seen to lie 'at the center of the perpetuation of inequality', it also has the potential to 'reduce inequalities' (De Ferranti et al. 2003, p. 303). Freire's (1972, p. 53) argument that the 'banking' approach to education 'attempts to maintain the submersion of consciousness', combined with Gramsci's (1971) concept of hegemony, would suggest that, in the classroom, all students are 'oppressed' until they have become 'critically conscious' (Freire 1972). One practical difficulty for critical pedagogy is thus Freire's emphasis on local contextualisation as a vital element for his methods, which contrasts with the need to emancipate huge numbers of people from oppression. The result of this difficulty is a predominance within critical pedagogy of either small local projects, or theoretical / analytical studies such as this one.

\section{Collective Focus (Social)}

Freire (1972, p. 49) considered one of the most crucial aspects of his pedagogy to be the use of 'discourse' or 'dialogue', creating partnerships between the 'revolutionary educator' and the student. Dialogue, in Freire's eyes, must be founded upon 'love, humility and faith' which, he maintains, will naturally evolve into a 'horizontal relationship of... mutual trust' (Freire 1972, p. 64). He contrasts genuine dialogue with 'assistencialism': 'policies of financial or social assistance which attack symptoms, but not causes, of social ills' and which tend to encourage 'silence and passivity', rather than equal dialogue, from those it aims to assist (Freire 1976, p. 15, footnote 1).

The focus on dialogue as 'one of the most significant aspects of critical pedagogy' (Darder et al. 2003, p. 15) allows critical pedagogy to counteract what Giroux (1997, p. 109) describes as the 'individualistic and competitive approaches to learning' of the 
neoliberal project and to promote to students a 'larger moral ecology beyond their own individual... concerns' (McLaughlin 1992, p. 243). Such a 'collectivity' helps students and teachers to 'see the limitations and lacunae in our own understandings' (Burbules and Berk 1999, p. 61) and to work 'solidaristically' towards a higher purpose (Hill 2003, p. 19).

From the perspective of citizenship educators, collectivism and a 'community of enquiry' in which to discuss social issues may help students 'build their capacity to become active and effective citizens' (Fisher 2008, p. 195). It is argued as crucial for those involved in collective dialogue to maintain their own identities in order to avoid 'groupthink... which is likely to result in irrational and dehumanizing actions directed against out-groups' (Janis 1982, p. 13). However, in general, critical pedagogues see 'selfemancipation' as 'contingent upon social emancipation' (Burbules and Berk 1999, p. 55) and therefore an approach to pedagogy which focuses on the collective is central.

\section{The Self / Subjectivity}

There is disagreement as to the extent that "objectivity" should be recognised as part of the critical. For example, Bowell and Kemp (2002, p. 257) argue that 'it is crucial for critical thinkers to recognise that truth is objective and not relative', and yet many postmodern critical pedagogues suggest that relativism is crucial, since it can provide a 'sense of hope and legitimacy for those Others' (Rust 1991, p. 619). Kuhn (1999) and Moon (2008) suggest that the important thing is for students to begin to understand the distinction between objectivity and subjectivity: 'the more sophisticated the critical thinker is, the more she will be aware of... the essential subjectivity of her reasoning' (Moon 2008, p. 61). 
Similarly, Gramsci (1971, p. 418) argued that intellectuals must feel 'the elementary passions of the people', and Freire (1972) reflected this idea within his writings: they are peppered with references to feelings and emotions and he closely analyses the potential emotional connections between oppressors and oppressed. The impression given is that emotions are essentially connected to morality: as Gray (2002, p. 42) argues, 'Morality is not a set of laws or principles. It is a feeling - the feeling of compassion for the suffering of others'. From a social constructionist perspective, education is a 'moral enterprise' because:

...we create a contrived environment, called "curriculum and instruction", and we attempt to influence persons in this environment. We assume the responsibility for the influencing of persons in the directions of our curriculum specifications, and this is essentially a moral act. (Macdonald 1966, p.39)

The philosophical arguments for and against a 'moral' education in schools are too lengthy to discuss here, but from the perspective of critical pedagogues, feelings, emotions and morals are crucial aspects of education. The sentiment is well captured by the survivor of a concentration camp who wrote, 'My eyes saw... Gas chambers built by learned engineers... Children poisoned by educated physicians... My request is: help your students become more human' (Unknown, cited in Pring 2004, p. 24).

\section{Praxis (Reflection, Action, Engagement and Possibility)}

Praxis, meaning the 'authentic union' of action and reflection which leads to conscientization (Freire 1972, p. 48), is perhaps the most distinctive element of critical pedagogy (Fischman and McLaren 2005; Kincheloe 2008; Morrow and Torres 2002). Freire (1972) warns educators that no real change can arise from an imbalance between reflection and action and he terms the sacrifice of reflection 'activism', and the sacrifice of action 'verbalism' (Freire 1972, p. 60, footnote 1). Similarly, Giroux (2003, p. 38) argues 
that praxis requires a fragile 'alliance' between theory and practice, 'not a unity in which one dissolves the other'.

'Reflection' by students should not simply be a superficial evaluation of 'what they have learnt... [and] the skills that they have developed' (Lawson 2005, p. 14) but should involve recognition of the 'causes of reality' (Freire 1972, p. 101). "True" praxis for critical pedagogues liberates humanity because it enables us to both perceive, from historical, cultural, economic, personal and political perspectives, and to act upon, the 'structures of domination' which oppress the people (ibid.). Hatcher $(2007$, p. 9) also suggests that 'the strategy of collective action... [should involve] parents, school students, local communities, and the whole constituency of working people and oppressed groups who have a common class interest'. However, effective action may begin with just a few players: for example, 'students and teachers fighting for the expulsion of a corporate influence in their schools' (DeLeon 2006, p. 7).

Giving students a critical sense of 'agency' may empower them towards conscientization (Freire 1972; Giroux 1997). However, for Aronowitz and Giroux (1986, p. 140), critical pedagogy must also 'attempt to link the languages of critique and possibility', if it is to have any hope of success in realising such agency. An optimistic and non-deterministic approach is therefore essential, fighting against the feeling that it is unrealistic to expect informed political deliberation from the mass public' (Niemi and Junn 1998, p. 1). The government, through the citizenship curriculum, may project an optimistic outlook for the future and, while this may be interpreted as a mask for the hegemonic oppression contained within (Aronowitz and Giroux 1986), it may also provide the necessary spaces for students and teachers to 're-construct the world' for the 'good of humanity' (Kincheloe 2008, p. 9). 


\section{Critical Citizenship}

\section{Conceptions of The Ideal Citizen}

We now analyse models of citizenship education that link to aspects of critical pedagogy, to identify what critical educators might envisage as the ideal citizen: i.e. the type of citizen they might be aiming for through their teaching projects and programmes, or, more cynically, the type of citizen they are allowed to aim for by the official curricula.

Crick (2008, p. 126) argues that the type of citizen valued by society is defined by the nature of their relationship with their government. Thus Galston's (1989) characterisations of the 'autarchic' and the 'autonomous' citizen inspired McLaughlin (1992, p. 245) to distinguish between 'minimal' and 'maximal' citizenship. The autarchic, or minimal, citizen is essentially obedient to government: 'law abiding' and 'public spirited' but with limited 'rational deliberation and self-determination' (ibid. 1992, p. 236). Conversely, the autonomous or maximal citizen 'actively questions' and has achieved a 'distanced critical perspective on all important matters' (ibid., p. 242).

Westheimer and Kahne (2004) and Veugelers (2007) complicate this minimalmaximal distinction by dividing citizens into three types. Despite the use of very different terms, their models are similar in the characteristics they ascribe to them ${ }^{2}$ and we have therefore amalgamated these in Figure 2 to show their commonalities. From the perspective of critical pedagogues, the critical democratic citizen (Veugelers) and the justice-oriented citizen (Westheimer and Kahne) are the ideal types as their defining features include a concern for social justice and a desire to improve society. 
Cogan and Derricott (1998, p. 155) construct a model of 'multidimensional citizenship' with four dimensions 'of thought, belief and action' (Cogan 2000, p. 22): the personal, the social, the spatial and the temporal. The foundational elements of this model (drawing from Marshall's (1983) classic work) describe a balance of desirable attributes for the ideal citizen, including: a sense of identity; the enjoyment of certain rights; the fulfilment of corresponding obligations; a degree of interest in public affairs; and an acceptance of basic societal values (Cogan and Derricott 1998, pp. 2-3). While these attributes are milder than those needed for truly critical citizenship, they illustrate the kinds of goals available for an ideal citizenship education, which we explore below.

\section{Models of Ideal Citizenship Education}

The IEA (International Association for the Evaluation of Educational Achievement) Civic Education Study (Amadeo et al. 1999) suggests that citizenship (or 'civics') education should be:

...cross-disciplinary, participative, interactive, related to life, conducted in a non-authoritarian environment, cognizant of the challenges of societal diversity and co-constructed with parents and the community... as well as the school. (Amadeo et al. 1999, p. 30)

Although this description mirrors some aspects of the writings of critical pedagogues, it focuses mainly on the process of constructing the curriculum rather than on the content itself and therefore can only go part-way towards helping the construction of the framework in the next section.

The term "citizenship education" is often characterised as the ideal out of the various terminologies used to describe social or political education. Kerr (2000, p. 209), for example, followed by Morris, Cogan and Liu (2002, p. 182) uses McLaughlin's (1992) 'minimal/maximal' model to distinguish between 'civic education' (education towards the minimal citizen) and 'citizenship education' (education towards the maximal citizen). 
Davies and Issitt (2005, p. 389) also differentiate between 'civics: provision of information about formal public institutions'; 'citizenship: a broad-based promotion of socially useful qualities'; and 'social studies: societal understanding that emerges from the development of critical thinking skills related to existing [school] subjects such as history and English'.

However, in practice many countries use subject labels which do not accord with these interpretations. France, for example, uses the term éducation civique (civic education) (Ministère de l'Education Nationale 2000) but, as Osler and Starkey (2005, p. iii) observe, this does not necessarily denote a minimal-style curriculum. Elements of citizenship education may also be covered in lessons across the globe entitled, variously, democratic education, humanities, social studies, world studies, society studies, moral education and life skills (Kerr 2000, p. 202). Using the term citizenship education as a 'catch-all', as we do in this study, is therefore appropriate and does not necessarily characterise any sort of ideal.

Both Kerr (2000, p. 208) and Criddle, Vidovich and O'Neill (Criddle et al. 2004, p. 31) argue that the suggested differences between 'passive and historical' and 'critical and active' citizenship education should not be a dichotomy but a 'continuum'. Kerr (2000, p. 210) expands his model to characterise three types: 'Education ABOUT Citizenship... Education THROUGH Citizenship... Education FOR Citizenship', similar to Parker's (1996) distinctions between 'traditional', 'progressive' and 'advanced' citizenship education. 'Education FOR Citizenship' being the ideal, Kerr's model suggests some critical elements but, like Cogan and Derricott's (1998) model, does not fully express the aims of critical pedagogy.

Osler and Starkey’s (1996) model again distinguishes between minimal and maximal, but argues for a 'holistic approach' (Starkey 2002, p. 5) in which the 'structural/political and the cultural/personal' are essential and intertwined elements of 
ideal citizenship education. As a liberal multicultural model, it is powerful in its depiction of otherness, which is very useful in a framework for critical citizenship education. However, its individualist focus highlights elements such as human rights, feeling and action without explicitly relating these to social interaction, dialogue, co-operation or praxis.

\section{Models of Critical Citizenship Education}

Several frameworks for citizenship education already possess an explicitly critical angle. Although each on its own does not cover all the elements of critical pedagogy examined above, we are able to adapt and combine many of the relevant aspects for our framework for critical citizenship education.

DeJaeghere (2006, p. 307) suggests that a 'critical approach' should replace the term 'maximal' as the ideal for citizenship education. Drawing on McLaughlin (1992), Cogan and Derricott (1998) and Westheimer and Kahne (2004), she argues that this critical approach would aim 'to provide the conditions for collective social change' through a combined focus on 'knowledge' and 'participation' (DeJaeghere and Tudball 2007, p. 49). This displays strong links to features of critical pedagogy as 'knowledge' refers to 'critical and structural social analysis' (specifically including 'asymmetries in power and the effects of colonization/decolonization'), representing the ideological/political elements of critical pedagogy described above; and 'participation' reflects elements of praxis, in actively examining 'relationships between the individual's behaviour in society and structures of social injustice' (ibid., pp. 48-49).

Also linked to critical pedagogy is Osler and Starkey's (1999, p. 213) checklist for effective citizenship projects, which includes 'co-operative practice'; 'independent reasoning and critical awareness'; and 'intercultural communication'. However, rather than considering the many types of oppressed peoples, it focuses on 'women' and 'ethnic 
minorities' (ibid.). It stipulates the teaching of information about human rights, but ignores any corresponding social responsibilities. 'Community involvement' (ibid.) is also a term which does not adequately reflect an engagement with praxis in the Freirean sense.

Andreotti (2006, p. 6) combines a postcolonial perspective with critical literacy in order to produce a classification of two types of global citizenship: 'soft' and 'critical'. This is a distinction which provides several elements for our analytical framework including analysis and critical reflection on one's own position/context and the addressing of complexities and power relations. However, its narrower focus on global citizenship prevents it from having the wider application to citizenship education in general.

Other writers in the field of critical pedagogy have also described ways of linking citizenship education and aspects of critical pedagogy. Apple and Beane (1995, p. 16), for example, argue that a 'democratic curriculum' should allow students to 'shed the passive role of knowledge consumers and assume the active role of "meaning makers"'. Parker's (1996, p. 117) 'advanced democracy' similarly advocates a citizenship that 'embraces individual differences [and] multiple group identities', aiming to unite these in 'democratic moral discourse'. DeJaeghere and Tudball (2007, p. 51) suggest that one way to achieve this is through 'contrapuntal pedagogy', as in 'the inclusion of non-mainstream literature, history and ideas that create new knowledge and understanding in contrast to dominant discourses', and this may be a useful perspective in developing students' sense of subjectivity, or 'the self'. In a similar vein, Grossman (2009) argues that democratic citizenship requires the use of a dialogic or conversational pedagogy which stresses the need for open and deliberative classroom discussions.

Giroux (1983, p. 168) makes an important distinction between 'training' students and using education to form a 'sound' character, and advocates an 'emancipatory rationality' for citizenship education, which focuses on 'macrostructural relationships', 
dialectically connected with 'how notions of consciousness, ideology, and power enter into the way human beings constitute their day-to-day realities' (Giroux 1980, p. 348). While Zaman (2006, p. 15) considers the practical implementation of Giroux's conceptions 'an impossible mission for institutions established, managed and financially supported by the state', they are helpful in the development of a framework for critical citizenship education.

\section{A Framework for Critical Citizenship Education}

As highlighted above, writers in the fields of citizenship education, critical pedagogy and critical thinking have developed a plethora of concepts and models to categorise and conceptualise critical citizenship. It is, however, possible to synthesise the literature to establish a 'framework' for analysing and comparing curricula which promote forms of critical citizenship. To allow us to identify and compare the features of critical pedagogy and citizenship education reviewed above, we have developed Table 1. This maps the key descriptors of critical pedagogy along the horizontal axis against the curricular manifestations on the vertical axis.

The four distinctive elements of critical pedagogy shown in Figure 1, above, form the horizontal categories of Table 1: politics/ideology, social/collective, self/subjectivity and praxis/engagement. For the vertical categories, we have used Cogan, Morris and Print's (2002, p. 4) useful definition of citizenship / civics education as the formation of 'the knowledge, skills, values and dispositions of citizens'. These terms can represent both individualistic attributes (for example, individual knowledge and skills) and the culture or 'ethos' (McLaughlin 2005) of an educational context (for example, communal values or dispositions). They are arguably conventional rather than radical terms, broadly reflecting the categories used in national curriculum documents. However, the use of this curricular 
terminology enables the framework (Table 2) to be applied by curriculum developers and teachers and to facilitate the analysis of existing curricular materials.

\section{Insert Table 1 about here}

Using Table 1 we have derived the 'framework for critical citizenship education' shown in Table 2, below. This has been achieved by distilling and simplifying the descriptions from Table 1, and by choosing those which align most closely with the tenets of critical pedagogy as analysed above, whilst retaining the four key elements distinguished in Figure 1: 'politics/ideology', 'social/collective', 'self/subjectivity' and 'praxis/engagement'. As Westheimer and Kahne (2004, p. 237) note, 'conceptions of democracy and citizenship have been and will likely always be debated - no single formulation will triumph'. The framework developed below is therefore intended to be a working, flexible model of critical citizenship, open to reinterpretation and adaptation.

Some elements that stand out as incompatible are discarded in the final cut (Table 2): for example, under the intersection between Praxis and Skills, the concept of 'participating actively and sensibly in roles and responsibilities one encounters in one's adult life' (Kerr 2000; McLaughlin 1992) contrasted with the other, more idealistic, elements of that section such as 'learning how to act collectively to build political structures that challenge the status quo' (Giroux 1980; Osler and Starkey 1999). The use of the word 'roles' could be interpreted as a symbol of social order or oppression, and the word 'sensibly' as a call to discipline and order, somewhat antithetical to the actively critical being (Veugelers 2007). 


\section{Practical implications of the framework}

From the framework a list of analytical questions central to the comparative study of curricula or teaching materials can be addressed. These include questions comparing policy intentions or actions across nations and comparisons within a nation of the curriculum with its various levels including curriculum intentions, the 'hidden' curriculum, the 'null' curriculum and their various concrete manifestations ranging from governmentrecommended schemes of work, regional guidance and textbooks to school programmes and classroom practice (Adamson and Morris 2007). Following such an analysis, the framework itself can be used as a pictorial representation to contrast the existence, opportunities for and absence of elements of critical citizenship within the various levels of a curriculum and its materials.

For example, key policy initiatives in the context of English citizenship education can be shown to align with particular sections of the framework. Crick's $(1998 ; 2008)$ conception of political literacy, hugely influential on the development of the English citizenship curriculum, would be strongly located in the top left hand corner of the framework (political knowledge), with 'active citizenship' elements drawn from the right hand column (praxis/engagement). In contrast, the Department for Education and Skills 'Diversity and Citizenship Report' (Ajegbo 2007) aims to promote elements from the middle two columns, particularly concerning self-knowledge and collective / social values. A forthcoming article uses the framework to compare the formal English and French citizenship curricula. Teachers and students in practice might also use the framework to explore their own experiences with critical citizenship. 
The framework may also be used to locate and contextualise within a broader context specific analyses of citizenship curricula. For example Jerome's (2006) study which analyses the experiences of trainee citizenship teachers in England implementing 'active citizenship' projects, and finds that interpretations of the term 'active citizenship' by teachers and school authorities can be very wide-ranging indeed, is situated within the 'praxis/engagement' column of the framework.

Clearly any attempt to develop such a framework has limitations and is open to a range of criticisms, most notably: the tendency to essentialise and dichotomise a complex range of viewpoints (De Lissovoy 2008); an overemphasis on the ideal at the expense of a concern for the implemented and hidden curriculum (Adamson and Morris 2007); and an analysis deeply rooted in a western liberal ideology which neither takes account of, nor recognises, the traditions of other cultures (Said 1978). As a classificatory and theoretical scaffold, any analytical framework for critical citizenship education cannot hope to offset these difficulties. It might, however, at least aim to provide an ideological support structure for teachers willing and able to connect with elements of critical pedagogy. Such problems might also be remedied in part by reinterpretations of the literature and models in future studies.

\section{Conclusion}

This paper has explored the elements which might be said to make up an ideal critical citizenship education. We have argued that four elements separate critical pedagogy from the more abstract and technical notion of critical thinking: ideology, collectivity, subjectivity and praxis; these were translated into language better associated with the curriculum: politics; society and interaction; the self; and reflection, action, engagement and possibility. Using these along with existing conceptual analyses and models of 
citizenship education, we have constructed a comprehensive framework for analysing critical citizenship education (Table 2). Both the implications and limitations of the framework were briefly explored.

While the official citizenship curriculum may be defined by the prevailing national political agenda and its socio-cultural context, it may still contain spaces that might be used by critical pedagogues to promote a strong ideological agenda. By mapping out the manifestations of these spaces onto a framework of critical citizenship, educators may evaluate and enhance their programmes and practice in order to achieve a true critical pedagogy: the emancipation and transformation of students and schools towards a better society.

\section{Endnotes:}

1. The theorists of the Frankfurt School themselves constructed the concept of "the authoritarian personality" (Adorno et al. 1950) from a psychoanalytical rather than economic perspective.

2. Differences between the models do exist: for example Westheimer and Kahne's (2004) 'participatory citizen' would most likely be much more socially aware than Veugelers' (2007) 'individualistic citizen'.

\section{References}

Adamson, B. and P. Morris. 2007. Comparing curricula. In Comparative education research: Approaches and methods, 263-82. Hong Kong: Comparative Education Research Centre, University of Hong Kong.

Adorno, T., E. Frenkel-Brunswik, D. Levinson and R. Sanford. 1950. The authoritarian personality. New York: Harper and Row.

Ajegbo, K. 2007. Diversity and citizenship : Curriculum review. [London]: Department for Education and Skills. http://publications.teachernet.gov.uk/eOrderingDownload/DfES_Diversity_\&_Citiz enship.pdf

Amadeo, J.-A., J. Schwille and J.V. Torney-Purta. 1999. Civic education across countries: Twenty four national case studies from the iea civic education project. Amsterdam, Netherlands: International Association for the Evaluation of Educational Achievement.

Andreotti, V. 2006. Soft versus critical global citizenship education. Development Education, Policy and Practice 3 (no. 1), http://www.osdemethodology.org.uk/texts/softcriticalvan.pdf (accessed 25th April 2009). 
Apple, M.W. 2000. Can critical pedagogies interrupt rightist policies? Educational Theory 50: $229-54$.

Apple, M.W. and J.A. Beane. 1995. Democratic schools. Alexandria, Va.: Association for Supervision and Curriculum Development.

Aronowitz, S. and H.A. Giroux. 1986. Education under siege : The conservative, liberal and radical debate over schooling. London: Routledge and Kegan Paul.

Arthur, J. and I. Davies. 2008. Citizenship education Sage library of educational thought and practice. London: Sage.

$\mathrm{Au}, \mathrm{W} .2007$. Epistemology of the oppressed: The dialectics of paulo freire's theory of knowledge. Journal for Critical Education Policy Studies 5 (no. 2), http://www.jceps.com/?pageID $=$ article\&articleID $=100\left(\right.$ accessed $20^{\text {th }}$ October 2009).

Barnett, R. 1997. Ed. Society for Research into Higher Education. Higher education : A critical business Society for research into higher education and open university press imprint. Buckingham: Society for Research into Higher Education \& Open University Press.

Bowell, T. and G. Kemp. 2002. Critical thinking: A concise guide. Vol. London of: Routledge.

Burbules, N.C. and R. Berk. 1999. Critical thinking and critical pedagogy: Relations, differences, and limits. In Critical theories in education: Changing terrains of knowledge and politics, 45-65. New York: Routledge.

Cogan, J.J. 2000. Multidimensional citizenship: A conceptual policy model. http://www.international.metropolis.net/events/washington/John_Cogan.doc.

Cogan, J.J. and R. Derricott. 1998. Citizenship for the 21st century : An international perspective on education. London: Kogan Page.

Cogan, J.J., P. Morris and M. Print. 2002. Civic education in the asia-pacific region: Case studies across six societies Reference books in international education. New York; London: RoutledgeFalmer.

Crick, B. 1998. Education for citizenship and the teaching of democracy in schools: The final report of the advisory group on citizenship. London: Qualifications and Curriculum Authority.

---. 2008. Basic concepts for political education. In Citizenship education, 123-39. London: Sage.

Criddle, E., L. Vidovich and M. O'neill. 2004. Discovering democracy: An analysis of curriculum policy for citizenship education. Westminster Studies in Education 27: 27-41.

Darder, A., M. Baltodano and R.D. Torres. 2003. The critical pedagogy reader. New York ; London: RoutledgeFalmer.

Davies, I. and J. Issitt. 2005. Reflections on citizenship education in australia, canada and england. Comparative Education 41: 389-410.

De Ferranti, D., G. Perry, F.H.G. Ferreira and M. Walton. 2003. Inequality in latin america and the caribbean: Breaking with history? Washington, DC: The World Bank.

De Lissovoy, N. 2008. Conceptualizing oppression in educational theory: Toward a compound standpoint. Cultural Studies $<=>$ Critical Methodologies 8, http://csc.sagepub.com/cgi/reprint/8/1/82 (accessed $20^{\text {th }}$ October 2009).

De Lissovoy, N. and P. Mclaren. 2006. Ghosts in the procedure: Notes on teaching and subjectivity in a new era. In The practical critical educator : Critical inquiry and educational practice, 151-65. Dordrecht: Springer.

Dejaeghere, J.G. 2006. Intercultural meanings of citizenship in the australian secondary curriculum: Between critical contestations and minimal constructions. In 
Reimagining civic education: How diverse societies form democratic citizens, 293317. Boston: Rowman-Littlefield.

Dejaeghere, J.G. and L. Tudball. 2007. Looking back, looking forward: Critical citizenship as a way ahead for civics and citizenship education in australia. Citizenship Teaching and Learning 3 (no. 2), http://www.citized.info/?strand $=6$ (accessed $20^{\text {th }}$ October 2009).

Deleon, A.P. 2006. The time for action is now! Anarchist theory, critical pedagogy, and radical possibilities. Journal for Critical Education Policy Studies 4 (no. 2), http://www.jceps.com/?pageID=article\&articleID=67 (accessed 20 $0^{\text {th }}$ October 2009).

Doddington, C. 2008. Critical thinking as a source of respect for persons: A critique. In Critical thinking and learning. Oxford: Blackwell.

Edelsky, C. and M. Cherland. 2006. A critical issue in critical literacy: "the popularity effect" In The practical critical educator: Critical inquiry and educational practice, 17-35. Dordrecht: Springer.

Fischman, G.E. and P. Mclaren. 2005. Rethinking critical pedagogy and the gramscian and freirean legacies: From organic to committed intellectuals or critical pedagogy, commitment, and praxis. Cultural Studies $<=>$ Critical Methodologies 5: 425-47.

Fisher, R. 2008. Teaching thinking: Philosophical enquiry in the classroom. 3rd ed. London: Continuum.

Freire, P. 1972. Pedagogy of the oppressed. Harmondsworth: Penguin.

---. 1976. Education, the practice of freedom. London: Writers and Readers Publishing Cooperative.

Galston, W. 1989. Civic education in the liberal state. In Liberalism and the moral life. Cambridge, MA: Harvard University Press.

Gibson, R. 1986. Critical theory and education Studies in teaching and learning. London: Hodder and Stoughton.

Giroux, H.A. 1980. Critical theory and rationality in citizenship education. Curriculum Inquiry 10: 329-66.

---. 1983. Theory and resistance in education : A pedagogy for the opposition Critical perspectives in social theory. London: Heinemann Educational.

---. 1992. Border crossings : Cultural workers and the politics of education. New York ; London: Routledge.

---. 1994. Toward a pedagogy of critical thinking. In Re-thinking reason: New perspectives in critical thinking. Albany: SUNY Press.

---. 1997. Pedagogy and the politics of hope: Theory, culture and schooling, a critical reader The edge: Critical studies in educational theory. Boulder, Colo.: Westview.

---. 2003. Critical theory and educational practice. In The critical pedagogy reader, 27 56. New York; London: RoutledgeFalmer.

---. 2005. Border crossings : Cultural workers and the politics of education. 2nd ed. ed. New York ; London: Routledge.

Gramsci, A. 1971. Selections from the prison notebooks of antonio gramsci. London: Lawrence and Wishart.

Gray, J. 2002. Straw dogs: Thoughts on humans and other animals. London: Granta.

Green, A. 1990. Education and state formation: The rise of education systems in england, france and the USA. London: Macmillan.

---. 1997. Postmodernism and state education. In Education, globalization and the nation state. Basingstoke: Macmillan.

Grossman, D.L. 2009. (in press) "Talking" About pedagogy: Classroom discourse and citizenship education. In Citizenship education pedagogies in asia and the pacific. 
Hong Kong: Comparative Education Research Centre, The University of Hong Kong, and Springer.

Hatcher, R. 2007. "Yes, but how do we get there?" alternative visions and the problem of strategy. Journal for Critical Education Policy Studies 5 (no. 2).

Hill, D. 2003. Global neo-liberalism, the deformation of education and resistance. Journal for Critical Education Policy Studies 1 (no. 1), http://www.jceps.com/? pageID $=$ article\&articleID $=7$ (accessed $20^{\text {th }}$ October 2009).

Janis, I. 1982. Groupthink. Boston: Houghton Mifflin.

Jerome, L. 2006. Critical citizenship experiences? Working with trainee teachers to facilitate active citizenship in schools. Teacher Development 10: 313-29.

Kerr, D. 2000. Citizenship education: An international comparison. In Education for citizenship. London: Continuum.

Kincheloe, J.L. 2008. Critical pedagogy and the knowledge wars of the twenty-first century. International Journal of Critical Pedagogy 1 (no. 1), http://freire.mcgill.ca/ojs/index.php/home/issue/view/6 (accessed 27 $7^{\text {th }}$ August 2008).

Kuhn, D. 1999. A developmental model of critical thinking. Educational Researcher 28: 16-46.

Lawson, N. 2005. What lessons does the pedagogical approach of paulo freire have for the development of citizenship as a national curriculum subject? , http://www.citized.info/pdf/students/Nick Lawson.pdf (accessed 27 $7^{\text {th }}$ August 2008).

Lipman, M. 2003. Thinking in education. 2nd ed. Cambridge: Cambridge University Press. Lukács, G. 1971. History and class consciousness. Cambridge, MA: MIT Press.

Macdonald, J.B. 1966. The person in the curriculum. In Precedents and promise in the curriculum field. New York: Teachers College Press.

Marshall, T.H. 1983. Citizenship and social class. In States and societies, 249-60. London: Open University / Martin Robertson (first published 1950).

Martin, J.R. 1992. Critical thinking for a humane world. In The generalizability of critical thinking. New York: Teachers College Press.

Marx, K. 1867/1999. Capital $i$. Oxford: Oxford University Press.

Mclaren, P. 2001. Bricklayers and bricoleurs: A marxist addendum. Qualitative Inquiry 7: 700-05.

---. 2003. Critical pedagogy: A look at the major concepts. In The critical pedagogy reader, 69-97. New York ; London: RoutledgeFalmer.

Mclaughlin, T.H. 1992. Citizenship, diversity and education: A philosophical perspective. Journal of Moral Education 21: 235-50.

---. 2005. The educative importance of ethos. British Journal of Educational Studies 53: 306-25.

Ministère De L'education Nationale, De L'enseignement Supérieur Et De La Recherche. 2000. Education civique juridique et sociale. http://www.education.gouv.fr/bo/2000/hs6/civique.htm.

---. 2004. Histoire, geographie, education civique: Programmes et accompagnement. Paris: Centre National de la Documentation Pedagogique.

Moon, J.A. 2008. Critical thinking : An exploration of theory and practice. London: Routledge.

Morris, P., J.J. Cogan and M. Liu. 2002. A comparative overview: Civic education across the six societies. In Civic education in the asia-pacific region: Case studies across six societies. New York; London: RoutledgeFalmer. 
Morrow, R.A. and C.A. Torres. 2002. Reading freire and habermas: Critical pedagogy and transformative social change. New York; London: Teachers College Press.

Niemi, R.G. and J. Junn. 1998. Civic education: What makes students learn. New Haven, CT; London: Yale University Press.

Osler, A. 1998. Conflicts, controversy and caring: Young people's attitudes towards children's rights. In Children as citizens: Education for participation. London: Jessica Kingsley.

Osler, A. and H. Starkey. 1996. Teacher education and human rights. London: David Fulton with support of the Council of Europe.

---. 1999. Rights, identities and inclusion: European action programmes as political education. Oxford Review of Education 25: 199-215.

---. 2005. Study on the advances in civic education in education systems: Good practices in industrialized countries. Geneva: International Bureau of Education, UNESCO.

Parker, W. 1996. "advanced" ideas about democracy: Toward a pluralist conception of citizen education. Teachers College Record 98.

Pring, R. 2004. Philosophy of education: Aims, theory, common sense and research: Continuum International Publishing Group.

Qualifications and Curriculum Authority. 2007. The national curriculum 2007: Citizenship programme of study for key stage 3 and attainment target. http://curriculum.qca.org.uk/ (accessed 23 ${ }^{\text {rd }}$ August 2008).

Rust, V.D. 1991. Postmodernism and its comparative education implications. Comparative Education Review 35: 610-26.

Said, E.W. 1978. Orientalism. London: Routledge and Kegan Paul.

Scatamburlo-D'annibale, V. and P. Mclaren. 2004. Class dismissed? Historical materialism and the politics of "difference". Educational Philosophy and Theory 36: 183-99.

Sen, A.K. 1999. Development as freedom. Oxford: Oxford UP.

Starkey, H. 2002. Active citizenship and the lifelong learning agenda. In Danish EU Presidency Conference, Lifelong Learning - Learning for Adults in the 21st Century. Comwell Helsingør, Snekkersten.

Tyack, D.B. and L. Cuban. 1995. Tinkering toward utopia : A century of public school reform. Cambridge, Mass. ; London: Harvard UP.

Veugelers, W. 2007. Creating critical-democratic citizenship education: Empowering humanity and democracy in dutch education. Compare: A journal of comparative education 37: 105-19.

Westheimer, J. and J. Kahne. 2004. What kind of citizen? The politics of educating for democracy. American Educational Research Journal 41: 237-69.

Wrigley, T. 2006. Opening the text: Voicing a future. In The practical critical educator : Critical inquiry and educational practice, 179-95. Dordrecht: Springer.

Zaman, H. 2006. Teachers perceptions of citizenship and citizenship education: A comparative study. Pittsburgh, PA: University of Pittsburgh.

http://etd.library.pitt.edu/ETD/available/etd-04202006123454/unrestricted/Dissertation2.pdf. 